

Mehry, a producer group member in Muminobod district of Khatlon province, Tajikistan. Photo credit: Ruby Wright/Oxfam

\title{
MAKING MARKET SYSTEMS
}

\section{WORK FOR WOMEN FARMERS IN}

TAJIKISTAN

A final evaluation of Oxfam's Gendered Enterprise and Markets programme in Tajikistan

DR MIRANDA MORGAN \& ALASTAIR STEWART






\section{CONTENTS}

Executive Summary .......................................................................... 3

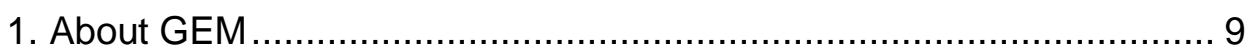

1.1. GEM in Tajikistan ......................................................... 9

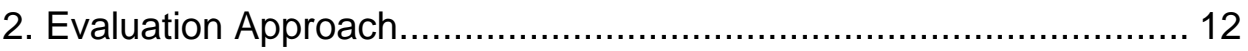

3. Results ............................................................................... 15

3.1. Influencing Market Systems ............................................ 15

3.2. Enhancing Smallholder Power in Markets ......................... 21

3.3. Increasing Women's Economic Leadership ......................... 26

4. Learning and Recommendations ................................................... 41

\section{ACKNOWLEDGEMENTS}

We would like to thank the staff of Oxfam Tajikistan for their support in carrying out this evaluation, with particular thanks to Seyed Faiz Hayat, Masuda Saidova, Mirzomurod Samiev and Farhod Khalikov.

Thanks are also due to Oxfam's partner organizations League of Women's Lawyers and Neksigol Mushovir. Oxfam acknowledges the smallholder farmers and wider stakeholders in Tajikistan who generously gave their time for this evaluation.

Fieldwork was conducted by Gulnora Beknazarova and Gulchegra Tabarova of Zerkalo Analytics Group, ably assisted by Ayubova Malohat and their team of enumerators.

Thanks also to Dave Bishop for conducting the quantitative data analysis. 


\section{EXECUTIVE SUMMARY}

In Tajikistan, the Gendered Enterprise and Markets (GEM) programme has been implemented in five districts of Khatlon Province by Oxfam in partnership with local public organizations, League of Women Lawyers of Tajikistan (LWL) and Neksigol Mushovir. Government departments, local authorities, the private sector and civil society were also key partners in the multi-stakeholder approach of GEM.

The GEM programme in Tajikistan sought to directly improve the livelihoods of an estimated 3,000 smallholder farmers (60 percent women) in fruit and vegetable value chains through improved production skills, resilience to climate risks, access to market opportunities and greater engagement with market players, and strengthened ability to influence private sector and government actors.

Figure 1: Snapshot of GEM programme outcomes in Tajikistan

\begin{tabular}{|c|c|c|}
\hline Intended Outcome & Rating & Commentary \\
\hline $\begin{array}{l}\text { 1.1. Improved policies } \\
\text { and practices benefiting } \\
\text { women smallholder farm- } \\
\text { ers }\end{array}$ & & $\begin{array}{l}\text { - } 2 \text { of } 10 \text { GEM recommendations in- } \\
\text { cluded in } 2016 \text { changes to the legal } \\
\text { code of the Farming Law, giving } \\
\text { women and men equal rights to land } \\
\text { in the event of divorce. } \\
\text { Examples of input suppliers and buy- } \\
\text { ers providing more and higher-quality } \\
\text { services directly to smallholder farm- } \\
\text { ers. }\end{array}$ \\
\hline $\begin{array}{l}\text { 2.1. Increased annual in- } \\
\text { come for women small- } \\
\text { holder farmers }\end{array}$ & & $\begin{array}{l}\text { Evidence of positive and significant } \\
\text { impact on household consumption } \\
\text { and investment. }\end{array}$ \\
\hline $\begin{array}{l}\text { 2.2. Increased quality of } \\
\text { income for women small- } \\
\text { holder farmers }\end{array}$ & & $\begin{array}{l}\text { Evidence is mixed: significantly higher } \\
\text { investment indicates project partici- } \\
\text { pants have sufficient trust in their in- } \\
\text { come to plan, yet some women farm- } \\
\text { ers said they found their new income } \\
\text { to be more unpredictable than the } \\
\text { crops they have longer experience } \\
\text { producing. }\end{array}$ \\
\hline $\begin{array}{l}\text { 3.1a. Increased decision- } \\
\text { making power of women } \\
\text { in households }\end{array}$ & & $\begin{array}{l}\text { Evidence of positive impact across all } \\
\text { household decision-making areas, } \\
\text { with significantly more project partici- } \\
\text { pants than non-participants reporting } \\
\text { joint or sole decision-making. }\end{array}$ \\
\hline $\begin{array}{l}\text { 3.1b. Increased decision- } \\
\text { making power of women } \\
\text { in communities }\end{array}$ & & $\begin{array}{l}\text { Evidence of positive impact: nearly all } \\
\text { GEM women farmers say they con- } \\
\text { tribute to decisions in their producer } \\
\text { groups, and there are examples of } \\
\text { women speaking and influencing de- } \\
\text { cisions in and beyond the community. } \\
\text { However, more GEM women say that } \\
\text { husbands get upset when women } \\
\text { speak out on public issues. }\end{array}$ \\
\hline
\end{tabular}

Evidence of positive and significant impact $\bigcirc$ Evidence of modest or mixed impact $\bigcirc$ No evidence of impact 


\section{Enhancing women's land rights}

The GEM programme was designed to influence stakeholders to shape markets (especially government and private sector actors) through improvements to policies for women smallholder farmers. For example, the programme conducted a series of round-table discussions on women's land rights to respond to the major barrier that land insecurity presents to women's participation in agricultural markets.

Through the influencing initiatives of the multi-stakeholder round table on women's land rights, two of 10 suggested recommendations were incorporated into the Farming (Dekhan) Law. Article 9 asserts that in cases of divorce, men and women have equal rights to the land property regardless of whom the land belonged prior to marriage. Having equal rights to the property also means that women now have the right to use the land to run a business and receive loans.

To aid sensitization of these changes to the law, 1,500 local government officials were trained on women's land rights and mobile legal clinics visited nearly 500 villages. However, despite efforts to promote local government ownership of these initiatives, there is no evidence that local government authorities are independently taking steps to promote awareness of women's land rights or to provide legal aid services that would support women to claim their rights in future.

Five district-level legal clinics were funded through the GEM programme and managed by the League of Women Lawyers. The legal aid clinics served approximately 8,000 clients during the programme, of which three-quarters were women. ${ }^{1}$ There is evidence of significant and positive impact for improved knowledge of women's land rights. In addition to improving women's legal literacy, the programme also contributed to more project participants seeking out legal information (on land access and family issues) than the comparison group.

\section{Market services}

The GEM programme was designed to influence stakeholders to shape markets through improvements to practices and services for women smallholder farmers. The programme sought to establish a multi-sectoral gender taskforce to encourage better interaction, understanding and coordination between actors shaping market opportunities for women. Activities were also targeted at increasing and improving the agricultural services available to women smallholder farmers, such as extension, input supply and market information services.

There is evidence that private companies are increasing their presence and service provision in the GEM project area. Input supply companies have established new stores reducing the distance that producers travel to buy quality seed from $160 \mathrm{~km}$ to $20 \mathrm{~km}$. One of these companies has started to provide inputs on credit to trusted farmers and is also providing

${ }^{1}$ Hayat, Seyed (2018) Gender, Enterprise and Markets in Tajikistan: Building Resilience, Empowering Lives. 
extension services, including field days, face-to-face or over-the-phone advice and distributing videos on DVD. A dried apple buyer has also delivered training to producer groups to improve the processing and quality of the final product, all be it on a relatively small scale. There is strong evidence of positive impact for the women GEM producers in terms of access to agricultural extension services and strong evidence of impact on adoption of improved agricultural production practices, including crop rotation and pest control.

There was weak positive evidence of GEM women farmers borrowing money (37 percent vs 27 percent in the comparison group). Women farmers explained that formal bank loans are not accessible to all as they can only access them if they have a family member in formal employment, and interest rates are too high. Selling household assets especially livestock - was reported to be the main strategy for women farmers to gain the investment capital they needed if they did not have access to formal loans.

\section{Crop revenues}

There is a positive and significant impact on the volume of tomatoes harvested, with the intervention group reporting producing far more than the comparison group and evidence of a strong positive impact on tomato sale values. In terms of apples harvested, again there is evidence of significant and positive impact with GEM project participants. However, no impact was observed on dried apple sales. Possible explanations are the small sample size ${ }^{2}$ and the timing of the household survey (during rather than after the harvest). Higher volumes, negotiation techniques, accessing markets outside of the village, and selling collectively were mentioned as key reasons for attaining higher revenues from the tomato crop. However, it was noted by buyers that prices for tomatoes in the region were much lower than elsewhere and some producers mentioned that they did not bother to negotiate as they were already receiving more revenue from increased production. Transporting produce to markets was raised as a barrier for many to accessing markets outside of the village.

\section{Incomes}

There is evidence of a positive and significant impact on household consumption, one of the main proxies for income. GEM project participants reported more daily total consumption (on food and non-food items) and monthly expenditure. There is also weak evidence of a significant impact on annual expenditure with GEM women farmers spending 37 percent more in the previous 12 months than non-GEM farmers. There is also evidence of positive and significant impact on investment.

GEM farmers expressed mixed views about the quality of income generated from the value chains. A few women mentioned that their

\footnotetext{
${ }^{2}$ Only 27 women in the entire sample reported selling in the last year (20 intervention; 7 comparison).
} 
income is now more frequent as GEM-sponsored training on preserving and canning has enabled them to sell these products and generate income in the winter for the first time. However, several project participants said they found income from selling tomatoes to be unpredictable, partly because, like other crops, it depends on changeable weather conditions and unstable market conditions.

\section{Women's decision making in households}

There is evidence of a positive and significant impact across all decisionmaking areas, meaning significantly more project participants than nonparticipants reported joint or sole decision-making. Both men and women said that while historically men have been responsible for generating and controlling the household income this has been changing in recent times with women having more influence over economic decision-making. Some of the reasons mentioned for women having more influence over economic decisions included women joining groups, gaining new knowledge, raised awareness on women's rights, and women contributing to household income.

Most agreed that women have more influence over economic decisions when they contribute income to the household. However, it still appears more difficult for women to spend their income independently than for men. Both men and women agreed that it tends to be easier for husbands to spend without consulting their wives, whereas it would be difficult or very difficult for a wife to spend without her husband's consent.

Almost all women said that they require permission from their husband to do anything outside the house. For many women this is only a courtesy to their husbands and not a significant barrier to participation. However, young women in particular face significant barriers to participating in new economic opportunities as they often lack decision-making power relative to their husbands as well as to the in-laws they tend to live with once married.

Significantly more project participants reported joint or sole decisionmaking on 'who cooks, cleans the house and takes care of people'. Furthermore, when asked which decision-making area they would like to have more control over, a smaller proportion of the intervention group (49 percent) said they wanted to have more control over 'who cooks, cleans the house and takes care of people' than the comparison group (85 percent), indicating that project participants perceive greater influence over unpaid care work than non-participants.

\section{Women's decision-making in communities}

The project has had a mixed impact on women's attitudes and opinions on their community and leadership roles. Significantly more GEM women farmers agreed that it is better for women to work together to solve problems than to work alone. Almost all women said they thought it was more effective to work together, and they planned to continue doing so once the programme finished. There is weak evidence of positive impact 
on women's comfort with speaking out in the community, with approximately three-quarters of project participants saying they agreed or strongly agreed with the statement, 'I feel comfortable speaking up in public to help decide on important decisions such as infrastructure to be built in my community'. But interestingly approximately the same proportion (and more than non-participants) said they agreed that husbands get upset when their wives speak out on public issues, indicating weak evidence of negative or undesirable project impact. It seems then that GEM women farmers may themselves feel more confident speaking out on public issues but do this despite the risk that their husbands will be upset with them for doing so.

\section{Gender-based violence}

There is high acceptability of violence across the sample: more than 80 percent of all women interviewed felt it was acceptable for a woman to be beaten by her husband in certain cases. There was, however, evidence of a positive and significant project impact on acceptability of violence, with significantly more GEM project participants saying that violence was unacceptable in all scenarios than non-participants.

Data shows that 31 percent of women in the project group reported awareness of any abuse in their community (physical or psychological) compared to 14 percent of the comparison group. The difference is statistically significant. Care must be taken when interpreting data such as this as there could be a number of explanations for higher levels of violence. The higher proportion of women in the intervention group reporting awareness of abuse in their community could mean that more violence is actually happening among GEM project participants and in GEM communities, potentially as a backlash to changing gender dynamics, and indicate negative project impact. However, it could also mean that participating in GEM makes women more likely to identify violence happening in their community and feel more comfortable discussing and reporting it.

The qualitative data generated by the evaluation indicates that the project did not lead to higher rates of domestic violence for GEM project participants. When asked about the link between gender-based violence and the programme, community members said they believed project participants themselves were not experiencing more violence and certainly not because of the programme. However, from secondary sources, there is evidence that domestic violence may have increased due to participation in the programme. The League of Women Lawyers reported that more cases of domestic violence were being reported year-on-year; while economic stress was cited as a main driver, some women said they believed the increase was due to a backlash from their spouse due to increased participation in community platforms like producer groups.

\section{Workload changes}

There is qualitative evidence from the focus group discussions that women have to increase their workload and sacrifice sleep in order to 
take advantage of economic opportunities without letting all their unpaid care work responsibilities slip. Women described the trade-offs between paid and unpaid work in general, but it was not specific to their participation in GEM, and according to the quasi-experimental analysis there is no evidence that the project had a negative impact on women's workload in relation to the comparison group. These findings show that if women want to engage in economic activities they have to conduct this on top of their care work responsibilities. This situation is experienced similarly across project and non-project communities. Focus group respondents also mentioned that if care work is redistributed, daughters and daughters-in-law are primarily responsible for the household work when older women are out of the house.

People in GEM communities did admit to men doing some of the unpaid care work in the household despite men and women generally being reluctant or hesitant to discuss men doing unpaid care work. Younger men in particular were seen to be more open to non-traditional gender roles, both encouraging their wives to be educated and work outside the home and more willing to take on household tasks themselves. Yet this does still seem to be the exception, and most men and women were much more comfortable with the concept of women working outside the home than men doing any unpaid work in the home. 


\section{ABOUT GEM}

Gendered Enterprise and Markets (GEM) is Oxfam GB's approach to market systems development. The GEM approach facilitates change in market systems and social norms, with the aim of ensuring more sustainable livelihood opportunities for marginalized women and men. The GEM Department for International Development (DFID) AidMatch Programme (June 2014-February 2018) works within the soya, milk and vegetable value chains targeting women smallholder farmers (SHFs) in areas of poverty. Some 63,600 people (10,600 smallholder households) living in Zambia, Tajikistan and Bangladesh were expected to benefit directly from this programme through increases in household income, women having greater influence over key livelihood decisions within their households and communities, and engaging in livelihoods more resilient to shocks, such as natural disasters and market volatility.

The programme works with a combination of private sector, government and civil society actors and supports improved public services, the development of new business models and improvements to linkages between smallholder farmers and small and medium agri-businesses. This engagement is being deepened and strengthened to consolidate gains and scale-up impact.

\subsection{GEM IN TAJIKISTAN}

In Tajikistan, the GEM programme has been implemented in five districts of Khatlon Province by Oxfam in partnership with local public organizations, League of Women Lawyers of Tajikistan (LWL) and Neksigol Mushovir. Government departments, local authorities, private sector and civil society were also key partners in the multi-stakeholder approach of GEM.

The GEM programme in Tajikistan seeks to directly improve the livelihoods of an estimated 3,000 smallholder farmers (60 percent women) in fruit and vegetable value chains through improved production skills, resilience to climate risks, access to market opportunities and greater engagement with market players, and strengthened ability to influence private sector and government actors.

The theory of action for the GEM Programme in Tajikistan details the intended pathways from the project activities, outputs, outcomes and intended impacts. The theory of action is aligned to the three impact areas:

1. Enhanced ability of women to influence decisions that affect their lives and well-being: this is achieved through the outcomes of increasing women's decision-making power at household and community level, increasing women's access to land, and challenging the acceptability of gender-based violence. The GEM programme in 
Tajikistan has sought to achieve this through establishing and strengthening producer groups to increase women's participation and leadership opportunities, training women producer group members on leadership and negotiation skills, establishing a multi-stakeholder gender taskforce and round table for discussion on women's land rights, and the provision of legal support for women through legal clinics and training.

2. Smallholder farmers have more power in agricultural markets: this is achieved by increasing the use of market services (information, input supply, extension) by smallholder farmers, increasing household income, improving the quality of income (frequency, predictability), and increasing the investment of household income into income generation strategies. The GEM programme in Tajikistan has sought to achieve this through training and exchange visits for smallholder farmers on improved production practices and value addition techniques, development of a mobile application for access to market and production information, establishing selling points in local markets for women traders, linking SHFs with market players, developing market services with the private sector, and building regional trade linkages between market actors in the north and south of Tajikistan.

3. Increased resilience of smallholder farmers to climatic and economic shocks: this is achieved through the outcomes of increasing farmers' access to credit and savings and increased adoption of vulnerability reduction strategies. The GEM programme in Tajikistan has sought to achieve this through the formation of village savings and loan groups and training for farmers on climate smart production techniques.

The theory of action diagram (Figure 2) visualizes the pathways from activities to outcomes and intended impacts. 


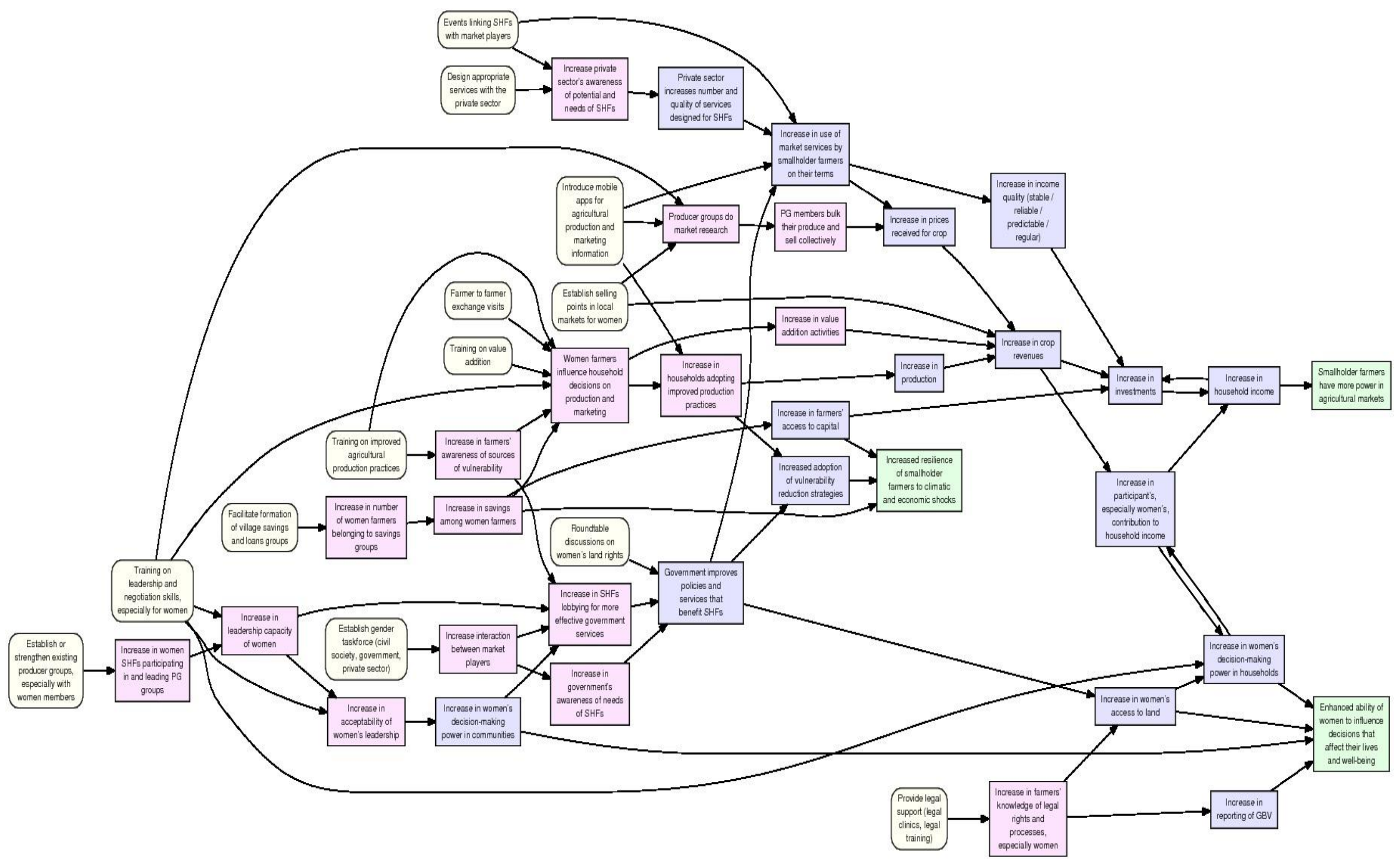




\section{EVALUATION APPROACH}

\section{Why evaluate?}

The purpose of the final evaluation was threefold:

1. To provide an opportunity for Oxfam, partners and a range of programme stakeholders to reflect on and learn from what and how change has happened due to the GEM programme.

2. To provide an opportunity for Oxfam GB and partners to learn more about select elements of GEM's theory of change within and across GEM countries.

3. To meet the requirement for accountability to DFID and programme stakeholders (especially project area community members) to measure the agreed impact and outcome indicators.

\section{How to evaluate?}

To achieve these goals, an evaluation approach was chosen that combined rigorous observation and analysis of changes at and across multiple levels (from individual to systems level) maximizing opportunities for learning for a range of stakeholders, including the people we work with ('project participants'3), local market systems actors, programme partners, Oxfam and DFID. Based loosely on the Participatory Impact Assessment and Learning Approach (PIALA) ${ }^{4}$ the evaluation aimed to combine rigour, inclusiveness and feasibility to assess the GEM programme and its contributions to change in several areas. The elements drawn from PIALA that differentiate this evaluation from others include:

- Stakeholders at all levels contributed to framing and designing the evaluation, and positioned the GEM programme theory of action within their larger theories of change.

- Mixed-methods data collection, analysis and triangulation to understand if the programme's desired changes occurred at multiple levels as well as how progress is enabled or challenged (see Box 1).

- Participatory sense-making workshops with the full range of stakeholders to cross-check and strengthen the findings, but also give stakeholders an opportunity to discuss the programme and to encourage local ownership and learning.

In addition, a process review was conducted by an external consultant to

\footnotetext{
${ }^{3}$ Also referred to as 'beneficiaries'.
}

${ }^{4}$ Heinemann, E., Van Hemelrijck, A. and Guijt, I. (2017) 'Getting the most out of impact evaluation for learning, reporting and influence: Insights from piloting a Participatory Impact Assessment and Learning Approach (PIALA) with IFAD.' https://maintenance.ifad.org/documents/10180/91825437-ffa9-4451-a7ef-9dbd5efbeba0 
better understand the factors that enabled or constrained effective programme implementation and sustainability with a view to using this learning to improve future programming.

Reflections (including limitations) of the above methods, fieldwork and analysis are outlined in Annex 5.

\section{Box 1: Complementary mixed methods}

Both quantitative and qualitative methods were used to observe if change occurred in key outcome areas and make plausible claims of contribution to the observed results, as well as to understand how change happens over time.

1. Household survey and quasi-experimental analysis: Interviews were conducted with 799 respondents (all women), of which 299 were directly supported by the project (referred to as the intervention group) and 500 were identified in neighbouring districts and communities where the programme did not conduct any direct activities (comparison group). To control for observable differences between these groups, Propensity Score Matching (PPM) was implemented resulting in 27 observations excluded and a total sample size of 772 . For more information on the quasi-experimental design (including sampling strategy and PPM) and analysis refer to Annex 1.

2. Focus Group Discussions (FGDs) in communities: FGDs were conducted in four communities targeted by the programme and involved at least 74 people in total (49 female, 25 male). Participatory FGD exercises were designed and conducted separately for different groups in each community: village leaders, female PG members, male PG members or family members of PG members (mostly husbands), and female PG members and non-members. For more information on the village selection criteria and tools refer to Annex 2.

3. Key Informant Interviews (KIIs) with market systems actors: During the design phase theory of change workshop, an outcome harvesting approach was used to identify potential systems-level outcomes. KIls were then conducted with eight stakeholders representing a range of market system actors to verify these outcomes. For more information on the $\mathrm{OH}$ approach and list of interviewees refer to Annex 3.

\section{What to evaluate?}

Like the GEM programme, the evaluation aimed to provide a holistic view of change and shed light on the multiple levels (from individual to systemic) and interconnected dimensions (economic, social, personal and political) of change that enable and sustain women's increased participation and power over time. ${ }^{5}$

The evaluation was designed to investigate if and how the GEM programme might have contributed to its intended outcomes - not only in

5 See Oxfam's fundamental principles for achieving sustainable, positive change for Women's Economic Empowerment, pp.23-24 in Kidder, T. et al. (2017) Oxfam's Conceptual Framework on Women's Economic Empowerment (https://policy-practice.oxfam.org.uk/publications/oxfams-conceptual-framework-on-womens-economicempowerment-620269) 
the lives of individual women smallholder farmers targeted by the programme (by enhancing their livelihoods or changing the way they influence decisions in their households, for example), but also to changes in their communities and the larger market system. It also sought to capture any potential unintended outcomes of the programme, especially those that are well known to manifest as negative outcomes in women's economic empowerment programmes (such as increased gender-based violence or amount of work).

The specific evaluation questions guiding the evaluation were primarily informed by the four impact indicators of the GEM programme log-frame. Table 1 shows the source of the main evaluation questions with links to the question numbers in the findings below.

\section{Table 1: Evaluation questions}

\begin{tabular}{|c|c|c|c|}
\hline \multirow[b]{2}{*}{$\begin{array}{l}\text { Changing } \\
\text { market } \\
\text { systems }\end{array}$} & \multirow[b]{2}{*}{$\begin{array}{l}\text { Global impact indicators } \\
1.1 \text { Number and type of } \\
\text { changes to local and } \\
\text { national policies and } \\
\text { practices related to } \\
\text { economic opportunities of } \\
\text { smallholder farmers, } \\
\text { especially women }\end{array}$} & \multicolumn{2}{|c|}{ Locally identified questions } \\
\hline & & $\begin{array}{l}\text { Has the GEM } \\
\text { programme facilitated } \\
\text { the creation of, and } \\
\text { access to improved } \\
\text { market services for } \\
\text { smallholder farmers? }\end{array}$ & $\begin{array}{l}\text { Q1, } \\
\text { Q2 }\end{array}$ \\
\hline \multirow[t]{2}{*}{$\begin{array}{l}\text { Enhancing } \\
\text { smallholder } \\
\text { power in } \\
\text { markets }\end{array}$} & $\begin{array}{l}2.1 \text { Average annual income } \\
\text { of beneficiary smallholder } \\
\text { farmer from horticulture } \\
\text { value chains }\end{array}$ & \multirow[t]{2}{*}{$\begin{array}{l}\text { Has GEM improved } \\
\text { productivity and } \\
\text { incomes? }\end{array}$} & \multirow[t]{2}{*}{$\begin{array}{l}\text { Q3, } \\
\text { Q4 }\end{array}$} \\
\hline & $\begin{array}{l}2.2 \text { Perceptions of } \\
\text { beneficiary smallholder } \\
\text { farmer on the quality } \\
\text { (timeliness, predictability, } \\
\text { stability, purpose) of their } \\
\text { income }\end{array}$ & & \\
\hline \multirow[t]{4}{*}{$\begin{array}{l}\text { Increasing } \\
\text { women's } \\
\text { economic } \\
\text { leadership }\end{array}$} & \multirow{2}{*}{$\begin{array}{l}\text { 3.1a Perceptions of women } \\
\text { in targeted communities on } \\
\text { their ability to engage in } \\
\text { decision-making processes } \\
\text { at household level, } \\
\text { especially economic and } \\
\text { care work responsibilities }\end{array}$} & $\begin{array}{l}\text { Do women (a) know } \\
\text { their legal rights to land } \\
\text { and (b) have secure } \\
\text { access to land? }\end{array}$ & \multirow[t]{2}{*}{$\begin{array}{l}\text { Q5, } \\
\text { Q6, } \\
\text { Q8 }\end{array}$} \\
\hline & & $\begin{array}{l}\text { Can women's economic } \\
\text { empowerment } \\
\text { (unintentionally) lead to } \\
\text { increased rates of } \\
\text { gender-based violence? }\end{array}$ & \\
\hline & \multirow[t]{2}{*}{$\begin{array}{l}\text { 3.1b Perceptions of women } \\
\text { in targeted communities on } \\
\text { their ability to engage in } \\
\text { decision-making processes } \\
\text { at community level }\end{array}$} & $\begin{array}{l}\text { What are the } \\
\text { perceptions of women } \\
\text { who work outside the } \\
\text { home? }\end{array}$ & \multirow[t]{2}{*}{$\begin{array}{l}\text { Q7, } \\
\text { Q8 }\end{array}$} \\
\hline & & $\begin{array}{l}\text { Do members plan to } \\
\text { continue working } \\
\text { collectively in producer } \\
\text { groups? }\end{array}$ & \\
\hline
\end{tabular}




\section{RESULTS}

The results below present a combined analysis of the quantitative and qualitative data to address the key evaluation questions. It should be noted that all survey respondents were women. This approach enabled greater statistical power in answering the questions of the programme's impact on women's incomes and empowerment.

When reporting the results from the quasi-experimental impact evaluation analysis, the results refer to the average difference between women living in communities where the project was implemented (the 'intervention group') and the matched women in communities where the project was not implemented (the 'comparison group'). As women in the comparison group represent an estimate of what would have happened to the project participants in absence of the project, the difference between the two groups represents an estimate of the project impact. In general, the results are reported as 'significant' if they have a p-value of less than 0.05 , but results with higher $p$-values (between 0.05 and 0.1 ) are also noted as 'weak evidence'; the lower the p-value the more confident we feel that the measured estimate reflects the true impact. Results with a $\mathrm{p}$-value of more than 10 per cent are not considered to be statistically significant.

\subsection{INFLUENCING MARKET SYSTEMS}

The GEM programme was designed to influence stakeholders to shape markets (especially government and private sector actors) through improvements to policies, practices and services for women smallholder farmers. For example, the programme conducted a series of round-table discussions on women's land rights to respond to the major barrier that land insecurity presents to women's participation in agricultural markets. The programme also sought to establish a multi-sectoral gender taskforce to encourage better interaction, understanding and coordination between actors shaping market opportunities for women. Activities were also targeted at increasing and improving the agricultural services available to women smallholder farmers, such as extension, input supply and market information services. 


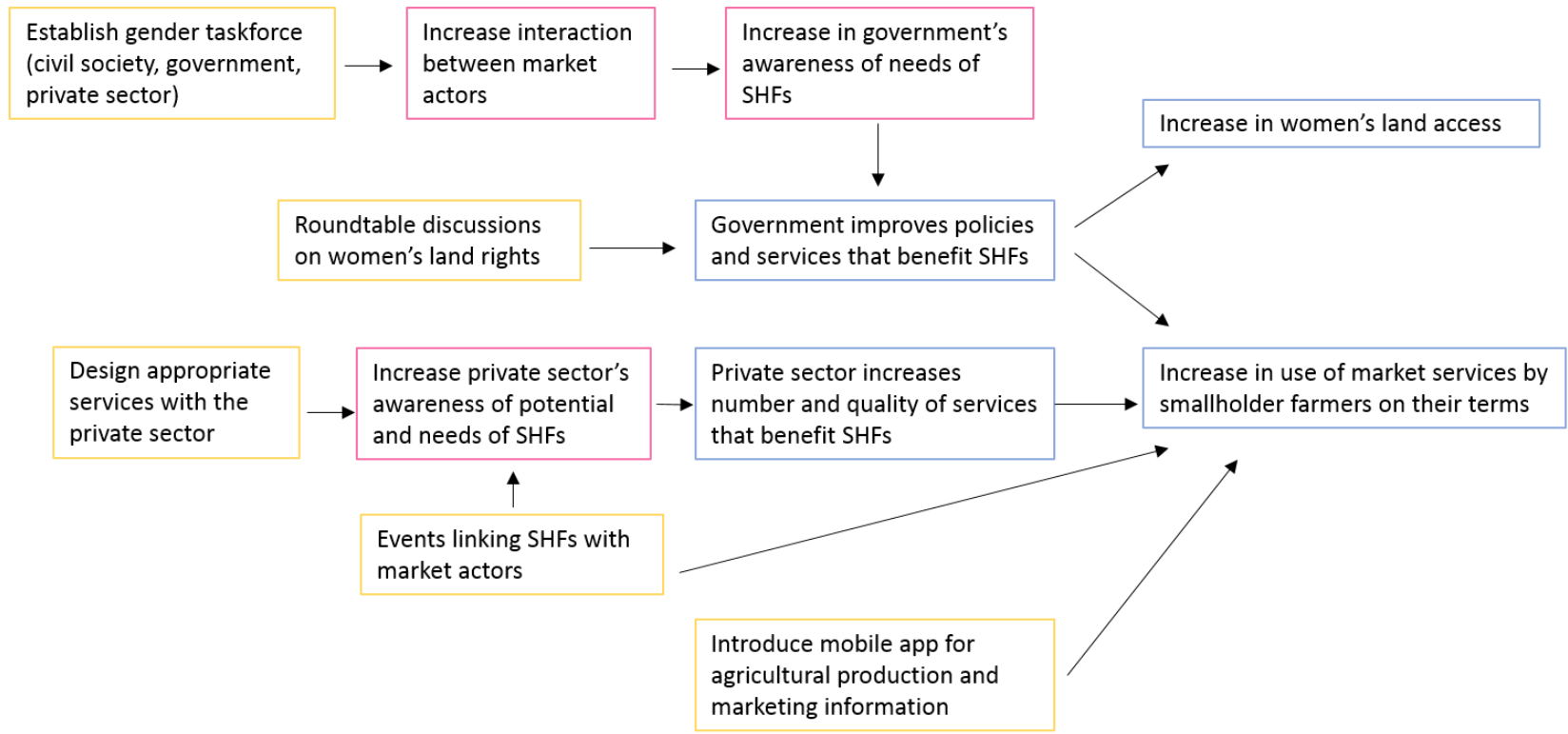

\section{Question 1: Has the GEM programme contributed to improved government policies and services that benefit women smallholder farmers?}

Women's lack of secure access to productive resources, especially land, was identified as a major barrier to their ability to take up new agricultural opportunities or benefit from markets. In response, the GEM programme took a multi-level strategy to address women's insecure access to land, including influencing national-level policy and legal frameworks related to women's land rights, training local government and village authorities, and establishing legal aid clinics to assist smallholder farmers, especially women, to secure their entitlements to land. This section will focus on the intended changes to legal frameworks governing women's land rights, with a latter section investigating whether this strategy led to the desired outcome of increasing women's access to land.

GEM partners Oxfam and the League of Women Lawyers conducted research on women's land rights and analysed existing legislation, then hosted a series of multi-stakeholder round-table discussions including with policymakers. In these forums and others, GEM partners advocated for changes to the policy and legal frameworks on land that would benefit women smallholder farmers in particular.

In March 2016, the legal code pertaining to the Farming (Dekhan) Law was changed and included two out of 10 recommendations put forward by GEM (now Articles 9 and 15 in the Farming Law). Now in cases of divorce, men and women have equal rights to the land property regardless of to whom the land belonged prior marriage. Having equal rights to the property also means that women now have the right to use the land to run a business and receive loans.

Legal changes were accompanied by efforts to sensitize people to the 
changes, in this case, ensuring that women know and claim their land rights. The programme aimed to do this by training local government authority and village officials on women's land rights and working with them on large-scale legal literacy campaigns. This included using mobile legal clinics to reach remote villages. By the end of the project over 1,500 officials had been trained and mobile legal clinics had visited nearly 500 villages. ${ }^{6}$ Local authorities said they appreciated the project's legal training and support on women's land rights and some even showed their support by hosting legal aid clinics and/or covering some of their expenses. Despite these positive signs, there is no evidence that local government authorities are independently taking ongoing steps to promote awareness of women's land rights or to provide legal aid services that would support women to claim their rights in future.

\section{Question 2: Has the GEM programme facilitated the creation of, and access to, improved market services for smallholder farmers?}

The GEM project worked in coordination with the private sector and government departments to develop and deliver a range of services that would encourage women smallholder farmers to participate in markets. This included the development of a mobile application ('AIMS') by Neksigol for production advice and market information on a variety of crops, establishing linkages between smallholder farmers and input suppliers and encouraging private sector buyers to engage in the provision of extension services.

\section{Buyers attracted to work in GEM project areas}

Interviews with buyers revealed there is a lot of interest in the southern areas of Tajikistan for their agricultural potential and quality of produce. GEM may have played a part in this as indicated by a tomato buyer who revealed that the quality of tomatoes in the region has improved significantly over the last two to three years. However, despite this, the prices were still much lower at 3 somoni per kilogram compared to 6 somoni per kilogram in other areas. Another buyer mentioned that the GEM project areas were attractive to buyers as there is the potential for earlier exports of onions and tomatoes.

However the agricultural potential that the southern areas offer is not matched in terms of market infrastructure that is available in the north of the country. Members of a local market committee mentioned the difficulty that producers face in transporting their produce to markets: 'since the yield increases with the year, it is necessary to bring them to the market in time and without losses, at this time our farmers deliver the tomatoes manually in boxes and buckets, which often leads to losses (tomatoes crack, the appearance is spoilt).' According to the local market committee, the majority of products are also sold at local level, and the
'You can get the harvest already in May, at a time when there are no such crops in the markets in the north of the country. In addition, if there are mechanized water in the north, then in the south there are mountain rivers. The soil in the south is also better than in the north. All these in total makes the south an attractive area for us.'

\footnotetext{
${ }^{6}$ Hayat, Seyed (2018) Gender, Enterprise and Markets in Tajikistan: Building Resilience, Empowering Lives.
} 
potential for exporting products could be increased if more processing and packaging facilities were available locally.

These findings, while not all relevant to the GEM project, are of use in planning future projects in the area. The private sector is increasing its interest in the agricultural potential of the area and future programmes should take into account the feedback of market players on transport and processing infrastructure.

\section{Input supply}

As the representative from the partner organization Neksigol Mushavir explained, access to improved inputs for farmers in the project area was a major challenge. To address this, Neksigol began to work with input suppliers Mehroj and Sadbarg to encourage them to establish input supply shops in the GEM project areas.

The input suppliers were initially reluctant to establish a presence in these areas claiming that they did not want to work in areas where farmers did not understand certified seed. So in addition to issues of a lack of access to quality seed the GEM project also worked with smallholder farmers to increase their understanding of the benefits of investing in quality seeds and inputs. 'The first year we could not convince farmers that quality seeds were the key to success. We told them, but... it's not entirely convincing. Having understood this, we created a demonstration centre to show how to use quality seeds. ${ }^{7}$

As a result, there are now input supply stores in Kulyab and Vose, reducing the distance that producers have to travel to buy quality seed from $160 \mathrm{~km}$ to $20 \mathrm{~km}$. The shop run by the company Sadbarg has started to provide inputs on credit to some trusted dealers and farmers with whom they have worked with for a few seasons. Data collected by the partner organization suggest that because of using improved tomato seed, yields in the region have doubled from 25-30 tonnes per hectare to 60 tonnes per hectare, with a record harvest of 145 tonnes from one hectare in Muminobod. An interview with a key tomato buyer in the region revealed it was not only the quantity of tomato production that had improved, but the quality also.

Women farmers across several communities said they have new understanding of where to access inputs like seeds and fertilizers, they have benefited from the new input supply shops and will continue visiting them in future and indeed that enhanced access to quality inputs was one of the main benefits of being involved in the programme. Interestingly, there was no statistically significant evidence that GEM women farmers were purchasing more fertilizer, and in fact only weak evidence that GEM women were purchasing less pesticides than the comparison group. While this seems to indicate that the programme has not had the impact it intended on enhancing access to inputs, GEM producer group members emphasized some changes to the way they source and use inputs that may explain this:

\footnotetext{
${ }^{7}$ Neksigol, Oxfam Partner
}

\section{'Over the past three years, the quality of agricultural products purchased in the village of Yakakapa has changed significantly. There have been large losses before as the products quickly deteriorated. Currently, tomatoes can last up to 10 days, high quality, and have a good marketable appearance. This increases the demand of customers for our products.}

Tomato buyer 
- GEM women farmers have started to buy inputs like pesticide collectively allowing them to benefit from the economy of scale but only use small amounts (and also means GEM women farmers may not have reported purchasing it for the household).

- GEM women farmers received training that improved the way they used fertilizers and pesticides and how much (and even to go without, employing new organic-friendly production techniques), allowing them to buy and use less but still improve productivity.

Significantly more GEM women farmers (18 percent) reported receiving inputs for free in the last 12 months than in the comparison group ( 6 percent); this would also explain why GEM women farmers report having enhanced access to inputs but do not report purchasing it. Women from several communities said they have gone on to purchase inputs after having received them for free, but it would be worth following up in future to understand the extent of uptake independent of project support.

\section{Extension services}

As part of the GEM project, Neksigol were responsible for the delivery of agriculture and value addition training for producer group members and wider communities through their demonstration and training centres. They also developed a mobile application to provide production and pest management advice, market prices and to link buyers and producers for sales opportunities. The application is available in Russian, Tajik and Uzbek and covers information on tomato, cucumber, onion, apple, apricot, vinegar, cabbage, potatoes, and lemon crops. The application can be downloaded onto Android phones so it is not expected that all farmers will have access to the application but instead a few producer group members and trainers can access the application and pass on the information to farmers when they are in the field. It is hoped that with the spread of smartphone technology more farmers will be able to directly access this information.

However, GEM also worked to develop non-project-based extension services to improve the likelihood of these services being sustained. With the input supplier Sadbarg starting to operate in the GEM project area, they are also providing consulting services. With the purchase of their inputs they provide production advice on sowing practices, pest management and weather conditions. These services are provided faceto-face or over the phone and they have also started to record consultations on CD which are distributed for free to customers.

A buyer of dried apples, Fruktovaya Doline, have also become involved in the provision of embedded extension services with GEM producer group members. When they first started working in the area they were not receiving products of the quality they needed. For apple drying there is no need for large investment or special technology just some basic knowledge on how to select, cut and dry the apples in a way that will meet buyers' expectations. The company trained producer groups on these techniques and emphasized the importance of working with women as part of a group to obtain the required volumes and for efficiencies on documentation processes. According to the respondent, "I would like to
'Farmer schools are an excellent opportunity to get to know farmers in the fields, to establish longterm relationships with them... We invite coaches from abroad or we conduct ourselves. In general, our participants are agronomists, farmers. And the participants, if they are newcomers, gradually begin to understand that we are serious partners. That we will be there if there are problems; that we are ready to teach and show; help with the solution of the problem. Thus, we build trust relationships with our customers.'

Input supply company 
increase the volume of farms. I generally like products from the Kulyab zone - Muminobod, Khovaling. There it is mountainous and the taste of products is different. There will be demand for this product.'

There was strong evidence of positive impact in terms of access to agricultural extension services; 71 percent of GEM women farmers accessed extension services in the last 12 months as compared to 5 percent of the comparison women farmers. There was also strong evidence of impact on adoption of improved agricultural production practices, with significantly more GEM project participants than nonparticipants reporting practising crop rotation (92 percent versus 75 percent) and pest control (94 percent versus 78 percent). During the sense-making exercise, participants said that they had applied what they had learned in training to manage serious issues they encountered with pests. They speculated that these techniques may have enabled more GEM farmers to report being able to earn income from their crops without interruption despite significantly more intervention than comparison households (67 percent and 38 percent respectively) reporting that their crops were affected by a destructive event, mostly pests, in the last 12 months.

Although access to extension services was significantly higher for the intervention group, the majority ( 57 percent) of project participants reported receiving extension services from GEM partner Neksigol. After GEM it is likely that those services will not be sustained on such a large scale, so it is important to understand whether GEM impacted access to non-project-related extension services. Promisingly, a greater proportion of GEM women farmers (approximately 30 farmers or 10 percent of the total intervention sample) said they received extension services from private companies as compared to 3 percent of the total comparison sample. The actual numbers of farmers is too low to show statistical significance but may indicate that those who participated in GEM were accessing some of the new extension services being offered by private companies discussed above.

\section{Market information}

Seventy-four percent (74 percent) of project participants said in the last 12 months they sought information on the price of the crop before selling, as compared to 31 percent of the comparison group; this is a positive and significant effect. The most frequently mentioned sources of price information by project participants were producer groups, the AIMS mobile application and NGOs.

\section{Weather information services}

There was a positive and significant effect on accessing weather forecasts with 63 percent of GEM women farmers saying they had done so compared with 31 percent of the women farmers in the comparison group. The most frequently reported sources of weather information by GEM women farmers were NGOs and the AIMS mobile application developed by GEM partner Neksigol. 


\section{Financial services}

Sixty-four percent (64 percent) of GEM women farmers surveyed said they would be able to borrow 5,000 somoni for a business opportunity (significantly more than the comparison group average of 44 percent), though only 37 percent reported borrowing any money in the previous 12 months (versus 27 percent in the comparison group, providing only weak evidence of programme impact on borrowing). GEM women farmers reported receiving their loans from formal banks, microcredit institutions and family members, while non-GEM farmers accessed loans from formal banks, family members and informal lenders. Just over 10 percent of GEM farmers also reported borrowing money from savings groups, compared to only 3 percent of non-GEM farmers.

During the sense-making in GEM communities, women farmers explained that while access to capital is vital for them to be able to invest in their production (to pay for inputs and fees to tractor drivers, for example) formal bank loans are not accessible to all; farmers can only access loans if they have a family member in formal employment who can apply with them. Furthermore, banks have high interest rates, which means revenues must be sufficiently high to enable them to repay loans and still profit. Selling household assets - especially livestock - was reported to be the main strategy for women farmers to gain the investment capital they needed if they did not have access to formal loans.

\subsection{ENHANCING SMALLHOLDER POWER IN MARKETS}

The theory of action set out a number of pathways by which GEM interventions would lead to increased smallholder incomes and power in markets. The evaluation relied on household survey data and quasiexperimental impact evaluation methods to assess the nature and extent of change GEM had brought about in incomes for women smallholders.

Figure 4: Snapshot of 'Enhancing Smallholder Power in Markets' pathway of theory of action

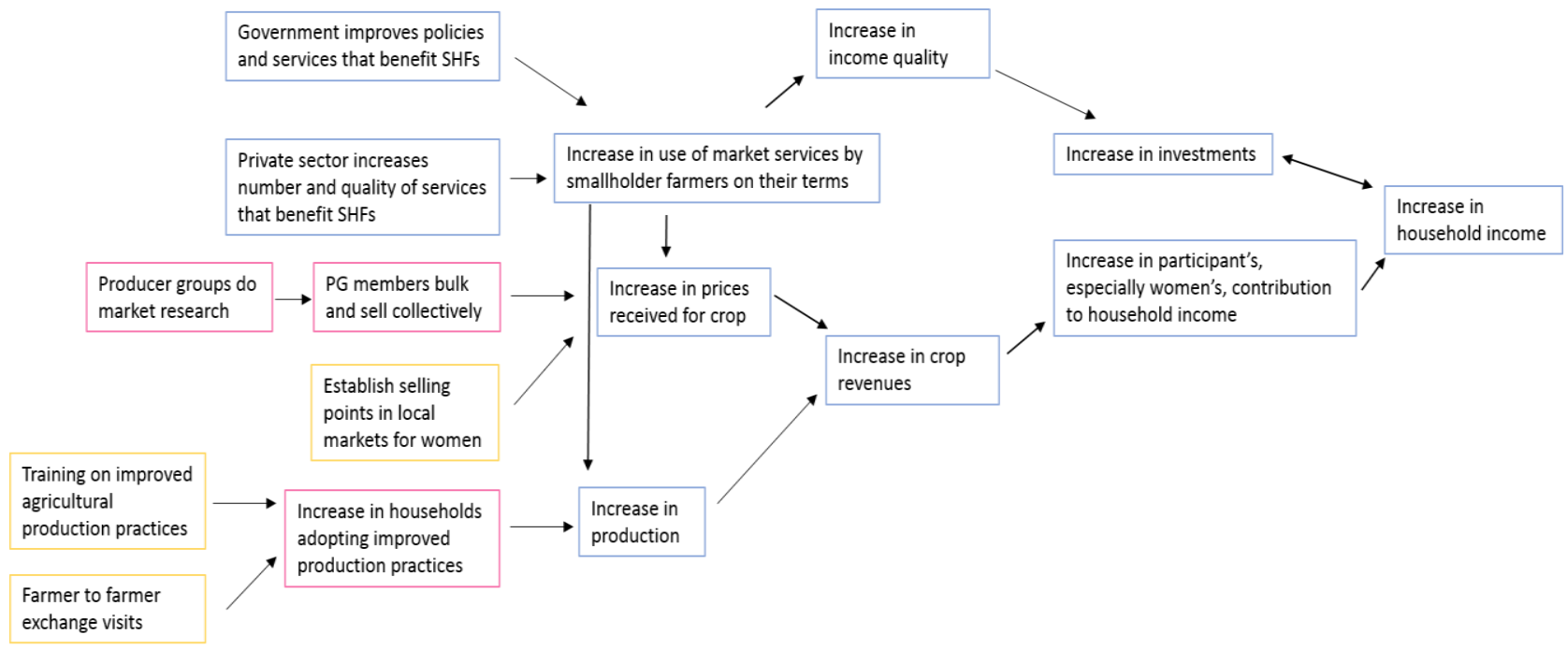




\section{Question 3: Have women smallholder farmers supported by the GEM programme experienced increased crop revenues?}

\section{Production and sales}

For production of all crops at household level the quasi-experimental analysis found that GEM households harvested approximately 3 tonnes of all crops in the previous 12 months compared to just over 2 tonnes in the comparison group; this was not a statistically significant difference. There is strong evidence of positive impact on proportion of harvest sold, with GEM-supported households selling on average 22 percent of their harvest in the last year versus 16 percent in the comparison group. Of the 284 intervention households that harvested, 190 (67 percent) sold at least part of their crop, as compared to 31 percent of non-project households who sold. Total sales from all crops averaged 4,467 somoni compared to 3,832 for non-GEM households. This is a difference of approximately GBP 50 per year and is not statistically significant.

Table 2: Breakdown of all crop, tomato and apple production and sales

\begin{tabular}{|c|c|c|c|c|c|c|c|c|}
\hline & $\begin{array}{l}\text { Sample } \\
\text { size }(n)\end{array}$ & \multicolumn{2}{|c|}{$\begin{array}{l}\text { Respondents' } \\
\text { harvested crop }\end{array}$} & $\begin{array}{c}\text { Volumes } \\
\text { harvested } \\
(\mathrm{kg})\end{array}$ & \multicolumn{2}{|c|}{$\begin{array}{l}\text { Respondents' } \\
\text { sold crop* }\end{array}$} & $\begin{array}{l}\text { Volumes } \\
\text { sold } \\
\text { (kg) }\end{array}$ & $\begin{array}{c}\text { Average } \\
\text { revenue from } \\
\text { sales (TJS) }\end{array}$ \\
\hline \multicolumn{9}{|l|}{ All crops } \\
\hline Intervention & 299 & 284 & $95 \%$ & 3,013 & 190 & $67 \%$ & 1,690 & 4,467 \\
\hline Comparison & 500 & 488 & $98 \%$ & 2,069 & 150 & $31 \%$ & 1,049 & 3,832 \\
\hline \multicolumn{9}{|l|}{ Tomato } \\
\hline Intervention & 299 & 271 & $91 \%$ & 463 & 118 & $44 \%$ & & 1,202 \\
\hline Comparison & 500 & 441 & $88 \%$ & 149 & 31 & $7 \%$ & & 381 \\
\hline \multicolumn{9}{|l|}{ Dried apple } \\
\hline Intervention & 299 & 106 & $36 \%$ & 223 & 20 & $19 \%$ & & 304 \\
\hline Comparison & 500 & 77 & $15 \%$ & 39 & 7 & $9 \%$ & & 208 \\
\hline
\end{tabular}

Notes: *Column shows percentage of producers that harvested who sold crop. See Annex 4 for further details on number of observations in each analysis for this and future tables.

When looking at the targeted value chains, over 90 percent of the women farmers in the total sample reported harvesting tomatoes in the last 12 months. There is positive and significant impact on the volume of tomatoes harvested with the intervention group reporting producing far more than the comparison group (463kg versus $149 \mathrm{~kg}$ ). Of those who harvested tomatoes, a greater proportion of project participants than nonparticipants reported selling them in the last year (44 percent of the intervention group versus 7 percent of the comparison group). In terms of apples harvested, again there is evidence of significant and positive impact with GEM project participants producing on average $223 \mathrm{~kg}$ versus non-participants who produced $39 \mathrm{~kg}$ (of those who reported producing apple, $n=183$ ). However as mentioned above it is not possible to observe impact in terms of dried apple sales values due to the small sample size. ${ }^{8}$

\footnotetext{
${ }^{8}$ Only 27 women in total reported selling dried apples, including seven in the comparison group
} 
There is evidence of a strong positive impact on tomato sale values with average tomato sales of 1,200 somoni for GEM women farmers as compared to 381 somoni for non-GEM farmers. ${ }^{9}$ Unfortunately, a similar impact could not be observed on dried apple sales, not necessarily because of lack of impact. Possible explanations are the small sample size, which makes it difficult to detect differences ${ }^{10}$ and the timing of the household survey (during rather than after the harvest).

\section{Price negotiation}

What could be contributing to the significant differences in sales values between project and non-project participants? One producer group member explains how she negotiates a price with a buyer: 'we first look at prices in the market [They can bargain with you] if they do not agree. Then we begin to say that we worked very hard to get this product. And if we give it for a low price, then it will be wrong.' But GEM women farmers in a community discussion said that they do not always bother negotiating; one woman known for her 'hard work' checks price information and is good at negotiating, but most say they accept prices that are offered to them. They said they feel satisfied to be receiving more revenue due to increased harvests resulting from improved production techniques and so do not bother trying to improve the prices as well.

\section{Market access}

The significant project impact on tomato sales value may also be partly explained by project participants' access to markets outside their own village. In general, farmers can receive higher prices for their crops when they sell them to markets outside their village, with some women saying they can receive 3 somoni for tomatoes outside the village, double the price of selling within the village. Of the $118 \mathrm{GEM}$ women farmers who reported selling tomatoes, the highest number (32 percent) said they mainly sold to a market outside their village, followed by selling to a market inside the village (22 percent) and to neighbours (15 percent). Given the small number of women in the comparison group who sold tomatoes ( 31 women), it is not possible to make meaningful comparisons between the intervention and comparison groups. But it is interesting to note that the most frequently mentioned main buyer for non-project participants was neighbours (12 women reported this) and only five said they sold to markets outside their village.

There are indications that women having more product to sell increases the likelihood of selling outside the village. This was verified during the sense-making in communities when larger producers said they were more likely to sell to markets outside the village than other women as the size of their harvest and surplus meant a higher earning potential that justified the transport costs and the time required.

\footnotetext{
${ }^{9}$ Analysis limited to only those who reported harvesting and selling tomatoes $(n=149$; 118 intervention, 31 comparison).

${ }^{10}$ Only 27 women in the entire sample reported selling in the last year (20 intervention; 7 comparison).
} 
Bulking and selling tomatoes collectively with other farmers may be another strategy enabling GEM women to access markets outside their village and receive higher prices for their tomatoes. There is strong evidence of positive impact on collective marketing of tomatoes with 42 percent of GEM tomato sellers reporting bulking tomatoes with other farmers prior to selling (versus 12 percent of tomato sellers in the comparison group). During one community discussion, a few women producer group members said when they pool their harvest they have one 'market focal point' who sells outside the village for all of them. She uses a GEM-established selling point especially for women in a nearby market.

\section{Question 4: Do women smallholder farmers supported by the GEM programme receive more and higher-quality income?}

The GEM programme sought to increase the overall household income of smallholder farmers (especially women) through enhancing their agricultural production and marketing in the tomato and dried apple value chains, and influencing the market system at large. To assess change in incomes the evaluation captured data on production levels and sales of key crops, and used household consumption and investment as proxies for household income.

\section{Increased income}

There is evidence of a positive and significant impact on household consumption, one of the main proxies for income. As the table below shows, GEM project participants reported more daily total consumption (on food and non-food items) (23 percent more than non-participants) and monthly expenditure (65 percent more than non-participants). There is also weak evidence of a significant impact on annual expenditure with GEM women farmers spending 37 percent more in the previous 12 months than non-GEM farmers. 
Table 3: Project impact on consumption, expenditure and investment

\begin{tabular}{|c|c|c|c|c|}
\hline & $\underset{(n=284)}{\text { GEM }}$ & $\begin{array}{c}\text { Compari- } \\
\text { son } \\
(n=488)\end{array}$ & $\begin{array}{c}\text { Project } \\
\text { effect }\end{array}$ & $\begin{array}{c}\text { Statistically } \\
\text { significant } \\
(\mathrm{p}=0.05) ?\end{array}$ \\
\hline \multicolumn{5}{|l|}{ Household consumption } \\
\hline $\begin{array}{r}\text { Total daily consumption } \\
\text { (Somoni per day per capita over past week) }\end{array}$ & 19.46 & 15.80 & $\begin{array}{l}+3.66 \\
(1.25)\end{array}$ & Yes \\
\hline $\begin{array}{r}\text { Daily food consumption } \\
\text { (Somoni per day per capita over past week) }\end{array}$ & 10.10 & 9.01 & $\begin{array}{l}+1.09 \\
(0.42)\end{array}$ & Yes \\
\hline $\begin{array}{r}\text { Daily non-food consumption } \\
\text { (Somoni per day per capita over past week) }\end{array}$ & 9.36 & 6.79 & $\begin{array}{l}+2.57 \\
(1.04)\end{array}$ & Yes \\
\hline $\begin{array}{r}\text { Monthly expenditure } \\
\text { (Somoni over past month) }\end{array}$ & 504 & 306 & $\begin{array}{l}+198 \\
(51.36)\end{array}$ & Yes \\
\hline $\begin{array}{r}\text { Annual expenditure } \\
\text { (Somoni over past } 12 \text { months) }\end{array}$ & 9,437 & 6,884 & $\begin{array}{c}+2,553 \\
(1336.09)\end{array}$ & No \\
\hline \multicolumn{5}{|l|}{ Investment } \\
\hline $\begin{array}{r}\text { Total invested } \\
\text { (Somoni over past } 12 \text { months) }\end{array}$ & 2,589 & 1,415 & $\begin{array}{c}+\mathbf{1}, \mathbf{1 7 4} \\
(1174.21)\end{array}$ & Yes \\
\hline $\begin{array}{r}\text { Total invested in farming, land and off-farm business } \\
\text { (Somoni over past } 12 \text { months) }\end{array}$ & 920 & 416 & $\begin{array}{c}+504 \\
(99.52)\end{array}$ & Yes \\
\hline
\end{tabular}

Notes: indicators are statistically significant when variables are expressed in logarithmic terms. Real values are presented here to give a sense of magnitude of incomes in the sample. See Annex 4 for further details on number of observations in each analysis for this and future tables.

There is also evidence of a positive and significant impact on investment (another proxy for measuring income) - both total household investment (amount spent on farming, land, off-farm businesses, education and health activities) and on household investment in farming, land and offfarm business:

- Total household investment: Over 99 percent of all households sampled reported investment in at least one activity in the last 12 months. On average, GEM households invested approximately 2,600 somoni in total, significantly more than non-GEM women farmers who invested approximately 1,400 somoni.

- Household investment on farming, land and off-farm business only: Out of the sample of households who invest, 73 percent reported investing in these activities specifically; a greater proportion of GEM households reported doing so than the comparison group (85 percent versus 66 percent). GEM households invest over 900 somoni on average, significantly more than non-GEM households who report an average of 400 somoni. This difference is statistically significant for the whole survey sample and also when narrowed down to only those households who reported investing in these activities.

\section{Quality of income}

When farmers have higher-quality (more timely, stable and predictable income) they can plan and invest in their business. The willingness of GEM women farmers to invest in their crops may be a sign that the income from targeted value chains is of higher quality. Yet, GEM farmers expressed mixed views about the quality of income generated from the value chains. On the one hand, a few women mentioned that due to GEM their income is now more frequent as GEM-sponsored trainings on preserving and canning has enabled them to sell these products and 
generate income in the winter for the first time. However, several project participants said they found income from selling tomatoes to be unpredictable, partly because, like other crops, it depends on changeable weather conditions and unstable market conditions and partly because tomatoes are new and more uncertain as compared to crops like wheat and cotton, which they have years of experience growing and feel more confident with predicting incomes.

\section{Beyond income? Improved well-being}

For community stakeholders, positive changes associated with the GEM programme went beyond just increases in the quantity and quality of income for an individual farmer (as it is narrowly defined in the logframe) to also touch on multiple dimensions of well-being for themselves and their families.

For example, people mentioned being able to spend more money on their children; for clothing, school fees or even being able to pay for them to attend university, as well as material benefits, such as improved food availability and diversity. One woman producer group member said, 'We have a lot of tomatoes, so we share with neighbours and they in turn give something we need like potatoes.'

They valued this ability to share and exchange with their neighbours, and said they felt happy and proud to be able to donate more food to the school or to poorer people in the village.

Participants also emphasized aspects of inner well-being, such as competence and self-worth. They highlighted the value of new knowledge gained from the training in the programme, mentioning training related to both agriculture and women's rights.

Some people discussed how participating in the programme improved relationships in households. One husband of a GEM farmer said it was more fun to work together with his wife. A female producer group member said that one of the benefits was that 'you can become closer with your husband'.

\subsection{INCREASING WOMEN'S ECONOMIC LEADERSHIP}

The GEM approach aimed to enhance the ability of women to influence decisions that affect their lives and well-being in their households and communities. Project activities, such as strengthening producer groups, providing skills training and building awareness on issues like genderbased violence and unpaid care, were implemented with the aim of improving women's assertiveness and fostering leadership. The evaluation sought to assess how well these activities translated into an increase in women's participation in and influence over decisions in the household and community. 




\section{Question 5: Do women know their legal rights to land and have secure access to land?}

The GEM programme took a multi-scalar approach to addressing women's insecure access to land - aiming to change national-level policy and legal frameworks as well as to work directly with women farmers to enable them to secure land. It was expected that interventions such as training, legal literacy awareness campaigns and legal aid services in communities would increase women's knowledge of their legal rights to land as well as their access to legal services to resolve land issues, leading eventually to more secure access to land.

During the household survey, respondents were asked two questions to assess anticipated project impact on improved knowledge of women's land rights. There is evidence of significant and positive impact for both questions:

1. Significantly more project participants than non-participants said they understood the meaning of 'joint marital property' (46 percent and 33 percent, respectively).

2. Significantly more project participants than non-participants gave the correct response (true) to the question 'According to law, when a couple divorces, women have equal right to the land' (94 percent and 83 percent, respectively)

In addition to improving women's legal literacy, the programme also contributed to more project participants seeking out legal information than the comparison group. Over 52 percent of GEM women farmers reported seeking information on land access (compared to 10 percent of non-GEM women), and 35 percent sought on information on family issues (8 percent of the comparison group); for both issues the difference between the intervention and comparison groups is statistically significant. 
The legal aid clinics served approximately 8,000 clients during the programme, of which three-quarters were women. ${ }^{11}$ While the data shows that GEM women farmers were more likely to access legal information than women from non-GEM communities, it should be noted that the legal services were not promoted exclusively, or limited only, to GEM producer group members. That said, producer groups did seem to provide a platform for women to learn about their rights and the number of producer group members accessing the services increased over the lifetime of the project.

There is evidence that the programme impacted women's knowledge of their legal rights to land and also improved their access to legal services. But did this help women to resolve their land issues and lead to more secure access to land? Nearly all women surveyed -96 percent of project participants and 95 percent of non-project participants - reported that their household holds a formal title to their land; there was no statistically significant difference between the intervention and comparison groups. But it must be stated that this data reflects only the household's access to land, not specifically women's access to land. ${ }^{12}$ Unfortunately, the survey data collected on land access could not be disaggregated by household members. ${ }^{13}$

The qualitative data generated provides some insights, revealing that women are normally able to access land for agricultural production, but many do not have secure access in the form of land titles. Those women often feel insecure about their future access (with negative effects on planning and investment) and/or face challenges in having to provide low-wage labour to dekhan heads to continue accessing their plot of land. Community members mentioned how the legal support provided by the GEM programme has helped to resolve land issues for some women (see sidebar quote). Another woman discussed some of the benefits of having her own land: 'During the Soviet time, then the women worked on the land. But they received little money. And now I have my own land and I make money. And I have all this now, because I know about my rights. Oxfam helped us very much.' Unfortunately, this has not been the experience of all women. In one community, a few women mentioned that despite the support they had received from the League of Women Lawyers they continued to face difficulties in securing access to their plots due to lack of documentation and/or powerful dekhan heads that refuse to recognize their rights.

\footnotetext{
${ }^{11}$ Hayat, Seyed (2018) Gender, Enterprise and Markets in Tajikistan: Building Resilience, Empowering Lives.

12 Previous research shows that land plots tend to only be registered in the name of the household head, most often a male; studies have found widespread exclusion of women's names from not only family farm certificates but also on documents stipulating the right of members to use collective dekhan farm lands, despite members being mostly women. In the process of land privatization (and allocation of legal titles) it is generally acknowledged that women have lost out and are underrepresented as land title holders (from Asian Development Bank, 2016, 'Tajikistan Country Gender Assessment')

${ }^{13}$ The survey question asked, 'Do you have a land title/certificate from the government for your land?'. Only women respondents were interviewed. However, we cannot tell if they were responding about their household having a land title or themselves.
} 


\section{Question 6: Do women smallholder farmers supported by the GEM programme feel they can influence key decisions in their household?}

The GEM programme aimed to generate new economic opportunities for women farmers as well as enhance their ability to make and influence key decisions in their households (especially economic-related), recognizing that this type of multifaceted strategy is required if women are to take advantage of and benefit from new economic opportunities. Increasing economic opportunities for women without simultaneous efforts to enhance women's agency makes it difficult to achieve or sustain women's economic empowerment, and worse it may even diminish women's well-being if it increases their workload, decreases the quality of their work or exposes them to violence but provides little benefit (more on potential unintended consequences in Question 8 below).

\section{Influencing economic decisions}

In the survey, women farmers were asked about whether they feel able to make or influence economic decisions in the household, such as what practices to use in crop production, and how to spend the income from farming, as well as about other decision areas, such as who does household work and their own mobility. There is evidence of positive and significant impact across all decision-making areas, meaning significantly more project participants than non-participants reported joint or sole decision-making. That said, only a very small proportion of the total sample were satisfied with their overall decision-making power; 83 percent of project participants and 98 percent of non-participants said there were decision-making areas that they would like more control over.
'We were visited by a woman lawyer from

Dushanbe and she worked with us a lot; showed us how to write a statement for the land and what to do. Then they helped in a situation where the land from one of our neighbours was taken away unfairly. The lawyers from Dushanbe helped us to solve this problem.'

Woman PG member 
Table 4: Project impact on women's decision-making in households

\begin{tabular}{|l|c|c|c|c|}
\hline $\begin{array}{l}\text { Proportion of women } \\
\text { who say they have joint } \\
\text { or sole decision-making } \\
\text { over: }\end{array}$ & $\begin{array}{c}\text { GEM } \\
\mathbf{( n = 2 8 4 )}\end{array}$ & $\begin{array}{c}\text { Com- } \\
\text { parison } \\
(\mathbf{n}=\mathbf{4 8 8})\end{array}$ & Difference & $\begin{array}{l}\text { Statistically } \\
\text { significant } \\
\mathbf{( p < 0 . 0 5 ) ?}\end{array}$ \\
\hline $\begin{array}{l}\text { Practices to use in crop } \\
\text { production }\end{array}$ & $77 \%$ & $56 \%$ & $\begin{array}{c}0.21 \\
(0.04)\end{array}$ & Yes \\
\hline $\begin{array}{l}\text { How to spend income from } \\
\text { farming }\end{array}$ & $81 \%$ & $43 \%$ & $\begin{array}{c}0.39 \\
(0.04)\end{array}$ & Yes \\
\hline $\begin{array}{l}\text { Who cooks, cleans the } \\
\text { house and takes care of } \\
\text { people }\end{array}$ & $91 \%$ & $79 \%$ & $\begin{array}{c}0.12 \\
(0.03)\end{array}$ & Yes \\
\hline $\begin{array}{l}\text { Whether you personally } \\
\text { can travel to visit relatives } \\
\text { outside the community }\end{array}$ & $88 \%$ & $66 \%$ & 0.22 & Yes \\
\hline $\begin{array}{l}\text { Whether you personally } \\
\text { can participate in } \\
\text { community group activities } \\
\text { or meetings }\end{array}$ & $90 \%$ & $40 \%$ & 0.50 & Yes \\
\hline
\end{tabular}

In focus group discussions in targeted communities both men and women said that while historically men have been responsible for generating and controlling the household income, this has been changing in recent times with women having more influence over economic decision-making. They mention several reasons contributing to this change, including male out-migration to Russia (as the women left behind take on more economic responsibilities and decisions) and presidential backing for policies that support women in education and employment, resulting in changing attitudes towards the value of girls' education and women's economic participation. According to men in one community, attitudes towards women working have changed a lot in the last ten years: 'It is clear that everything has changed. Women began to work, and we saw that they could work...work allowed them to change their situation'.

Some of the reasons mentioned for women having more influence over economic decisions can also be linked to GEM interventions. For example, in community discussions, women's recent increased influence in household decisions were attributed to:

- Women joining groups, which help them to learn new skills (such as assertiveness), develop confidence and sometimes even take leadership positions.

- The useful content of the agricultural training provided by Neksigol so that when women take it back to the household men also want to apply the new knowledge. 
- The training on women's rights and family issues provided by LWL (women in one focus group discussion said they feel they have more power at home because the training helped them to know their rights).

- Women selling agricultural products and contributing income to the household, often for the first time. This enables them to make decisions related to the income that they bring in and also appears to spill over into other household decisions (for example, one producer group member said, 'When I started making money, and my husband saw that I am earning too, he started to understand... now we are talking about everything.'

- 'When I started making money, and my husband saw that I am earning too, he started to understand... now we are talking about everything.'

There seems to be a positive feedback loop between women's income and their influence over economic decisions in the household: a critical level of initial household decision-making power is required for them to be able to join groups, take advantage of new economic opportunities and increase their income (influence in household decision-making $\rightarrow$ increased income); but once they have income this enables them to take more decisions on selling, spending and future production, thus expanding their influence over household decisions over time (income $\rightarrow$ increased influence in household decision-making). Men and women across all community discussions emphasized that once women show they can bring income and profit to the family then husbands are less likely to prevent their wives from making key economic decisions or doing the selling. In fact, now that women are doing more of the selling they are proving themselves to be better at selling than the men. One producer group member said that she was able to get higher prices than her husband used to: 'Previously our men sold our tomatoes. They thought that women cannot do this. They themselves sold a very cheap crop. For example, beans were sold for 2 somoni. And now we are selling for 12 somoni.' And some men also agreed with this; as one said, 'I think it is better for women to find products... if I sell I can sell very cheaply but my wife will bargain and can sell the goods for a good profit.'

As Table 5 demonstrates, the programme may have positively impacted some but not all attitudes towards women in economic roles; significantly more GEM project participants agreed positively on two statements on women working outside the home. But there was no impact observed on two other attitudinal statements on women's entrepreneurship and income. Over 80 percent of the total sample said they believed that men make better entrepreneurs than women and almost half of the sample agreed that if a woman earns more money than her husband it will almost certainly cause problems. 
Table 5: Project impact on attitudes towards women's economic roles

\begin{tabular}{|l|c|c|c|c|}
$\begin{array}{l}\text { Proportion of women who } \\
\text { 'agree' or 'strongly agree' } \\
\text { with the statement: }\end{array}$ & $\begin{array}{c}\text { GEM } \\
(\mathbf{n = 2 8 4 )}\end{array}$ & $\begin{array}{c}\text { Comparison } \\
(\mathbf{n = 4 8 8 )}\end{array}$ & Difference & $\begin{array}{c}\text { Statistically sig- } \\
\text { nificant } \\
(\mathbf{p}<\mathbf{0 . 0 5})\end{array}$ \\
\hline $\begin{array}{l}\text { 'Having a job is the best way for a } \\
\text { woman to be an independent per- } \\
\text { son' }\end{array}$ & $98 \%$ & $83 \%$ & 0.15 & Yes \\
\hline $\begin{array}{l}\text { 'If the wife is working outside the } \\
\text { home, the husband should help her } \\
\text { with chores' }\end{array}$ & $93 \%$ & $88 \%$ & 0.05 & Yes \\
\hline $\begin{array}{l}\text { 'If a woman earns more money } \\
\text { than her husband, it's almost cer- } \\
\text { tain to cause problems' }\end{array}$ & $48 \%$ & $43 \%$ & 0.05 & No \\
\hline $\begin{array}{l}\text { 'On the whole, men make better } \\
\text { entrepreneurs than women' }\end{array}$ & $83 \%$ & $80 \%$ & $\begin{array}{c}0.03) \\
(0.04)\end{array}$ & No \\
\hline
\end{tabular}

In the discussions, most agreed that women have more influence over economic decisions when they contribute income to the household, but there is still a question regarding the extent women control the income they derive. According to some women producer group members, they are able to spend the money they now earn, and indeed this was cited as a main benefit of participating in the GEM programme. One woman explained what the situation was like before: 'Five years ago almost all women had no money on their hands. We strongly depended on men, we could ask only men for money.' But now they do not have to turn to their husbands for every purchase. Another woman said, 'Two years ago I asked for everything. I have five children at school and spend money for them and now I do not need to ask about it. Everything I need I buy from my earnings.'

Despite these experiences, it still appears more difficult for women to spend their income independently than for men. During men's and women's focus group discussions, participants were asked to vote secretly on how easy or difficult it would be for a wife or husband to go ahead and spend the money they themselves earned or inherited. In general, both men and women agreed that it tends to be easier for husbands to spend without consulting their wives, whereas it would be difficult or very difficult for a wife to spend without her husband's consent (see Figure 6).

So, while household dynamics may be starting to change, it appears far from equal, and men are likely to have a large say in what happens to the income women generate. The challenge in women spending income independently may also be related to the nature of the work. When it comes to agricultural production, which tends to be shared among household members, as opposed to a salaried job which one would do independently, it is not as easy to delineate women's labour from men's and therefore her earnings. While the GEM programme primarily targeted women to join producer groups, receive training and so on, it is likely that the labour involved in generating income was not done by the targeted woman alone and thus it is not only 'her' earnings. This was pointed out in a focus group discussion where one male partner said, 'In general, if 
the husband does not help, then it is impossible to earn a lot of money. For example, you need to collect one ton of tomatoes. How can she harvest it herself? Her husband will help her. And this means that she is not the only one who earns this money.' The type of work involved clearly has implications for who has the right to independently spend income, in addition to gendered household dynamics.

Figure 6: Men's and women's perceptions of spending earned income

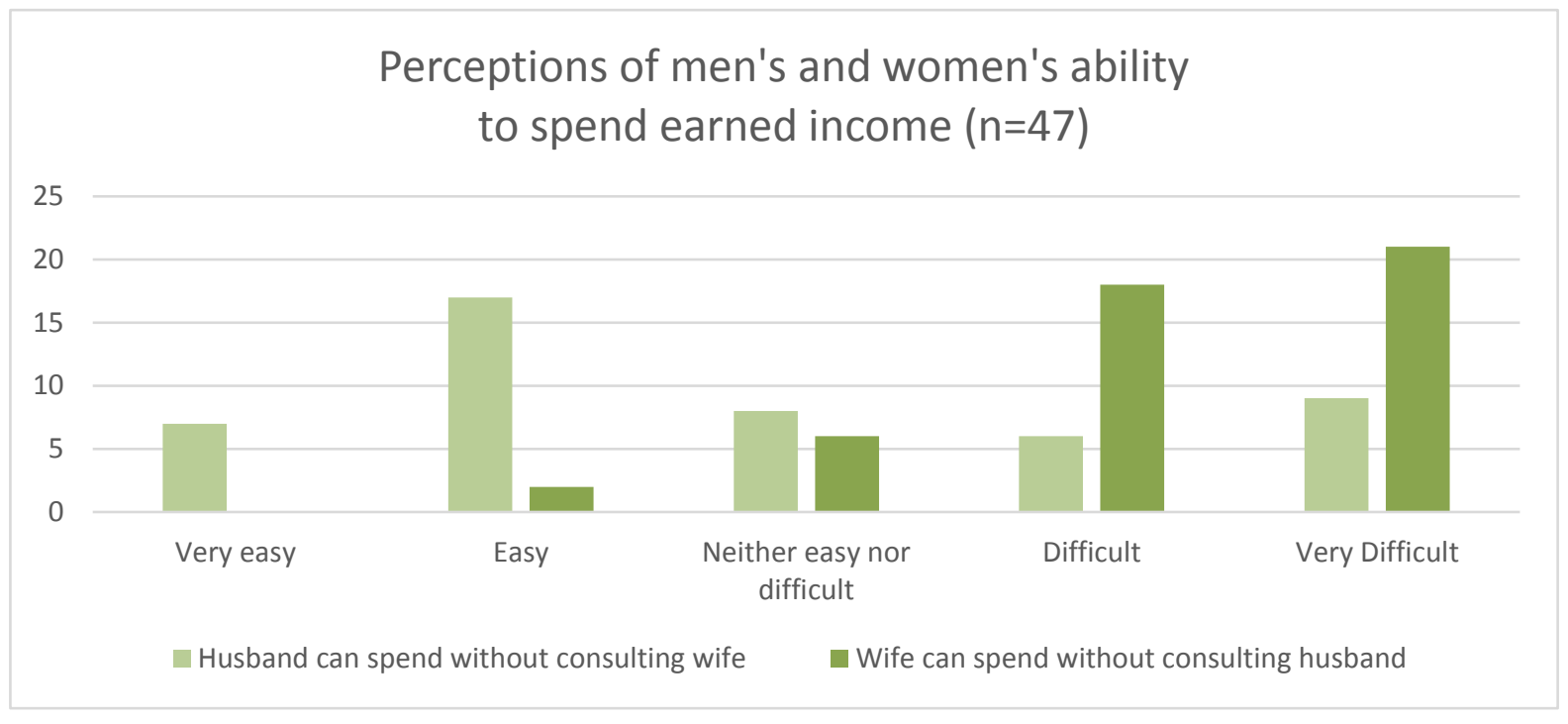

\section{Influencing decisions on unpaid care work}

Addressing the heavy and unequal responsibilities of women for unpaid care work ${ }^{14}$ is crucial in its own right. It is also a vital strategy in achieving women's economic empowerment as women's time poverty is clearly a barrier to women accessing and maximizing benefit from new economic opportunities.

Significantly more project participants (91 percent) than non-participants (79 percent) reported joint or sole decision-making on 'who cooks, cleans the house and takes care of people'. Furthermore, when asked which decision-making area they would like to have more control over, a smaller proportion of the intervention group (49 percent) said they wanted to have more control over 'who cooks, cleans the house and takes care of people' than the comparison group (85 percent), indicating that project participants perceive greater influence over unpaid care work than non-participants.

\section{Barriers to participation in economic opportunities}

For women to even begin to benefit from economic opportunities they must first be able to participate in them. While this section has largely focused on the changes for women who participated in GEM activities like producer groups, training or marketing, there are many women who were not able or allowed to join, those who did not have that initial critical level of household decision-making power that is required to kickstart the positive feedback loop from income $\leftarrow \rightarrow$ increased influence. Almost all

\footnotetext{
${ }^{14}$ Defined for the evaluation as care of children and elderly, cooking, cleaning and washing, and collecting water
} and firewood 
women said that they require permission from their husband to do anything outside the house. For many women this is only a courtesy to their husbands and not a significant barrier to participation. However, community discussions highlighted how some women, especially young women, are prevented by their husbands or in-laws from leaving the house.

Young women in particular face significant barriers to participating in new economic opportunities. During focus group discussions men and women said that young women are not expected to speak up or participate in household decision-making. As one woman explained, 'At 40, a woman can say something to a man. And before that, she cannot say anything. She does not have the right to voice.' They often lack decision-making power relative to their husbands as well as to the in-laws they tend to live with once married. Even if a young woman is able to ask for and obtain permission from her husband or in-laws to participate in economic activities outside the house, people said her heavy responsibilities for unpaid care work in the household (even relative to older woman in the house) often prevents her from doing so. Younger women often have larger care duties due to having young children or having to take care of the extended family, compounded by not being able to ask for help. In a community discussion in the sense-making, a young woman explained that though her new husband may be willing to help out with the household work she could not ask him: 'How can I ask him to support me? I live with his parents and am scared to ask.'

\section{Question 7: Do women smallholder farmers feel more capable of making and influencing decisions in their communities?}

There is evidence that GEM has had a positive and significant impact on women's participation in groups. In the intervention group, 99 percent of women reported being a member of a producer group and only 2 percent of the comparison group reported producer group membership. It is slightly higher for the comparison group in terms of savings group membership (11 percent) but still significantly less than among GEM women farmers (36 percent). Nearly all GEM women famers (98 percent) say they are involved to some or a large extent in decision making in their producer groups, with the greatest proportion saying they significantly contributed to decisions on buying inputs.

The project has had mixed impact on women's attitudes and opinions on their community and leadership roles. Firstly, significantly more GEM women farmers (98 percent) agreed that it is better for women to work together to solve problems than work alone, compared to 93 percent of non-GEM farmers. During community discussions, almost all women said they thought it was more effective to work together and they planned to continue doing so once the programme finished. Secondly, there is weak evidence of positive impact on women's comfort with speaking out in the community, with approximately three-quarters of project participants

\section{'At 40, a woman can say something to a man. And before that, she cannot say anything. She does not have the right to voice'.}

Woman PG member 
saying they agreed or strongly agreed with the statement, 'I feel comfortable speaking up in public to help decide on important decisions such as infrastructure to be built in my community'. But interestingly approximately the same proportion (and more than non-participants) said they agreed that husbands get upset when their wives speak out on public issues, indicating weak evidence of negative or undesirable project impact. It seems then that GEM women farmers may themselves feel more confident speaking out on public issues, but do this despite the risk that their husbands will be upset with them for doing so, with potentially negative implications for women's relationships as well as their individual safety and well-being (more on this in Question 8 on programme impact on gender-based violence).

\begin{tabular}{|c|c|c|c|c|}
\hline $\begin{array}{l}\text { Proportion of women who } \\
\text { 'agree' or 'strongly agree' } \\
\text { with the statement: }\end{array}$ & $\begin{array}{l}\text { Interven- } \\
\text { tion } \\
(n=284)\end{array}$ & $\begin{array}{l}\text { Compari- } \\
\text { son } \\
(n=488)\end{array}$ & Difference & $\begin{array}{l}\text { Statistically signifi- } \\
\text { cant }(p<0.05) ?\end{array}$ \\
\hline $\begin{array}{l}\text { 'It is better for women to work to- } \\
\text { gether to solve problems than } \\
\text { working alone' }\end{array}$ & $98 \%$ & $93 \%$ & $\begin{array}{c}0.05 \\
(0.02)\end{array}$ & Yes \\
\hline $\begin{array}{l}\text { 'I feel comfortable speaking up in } \\
\text { public to help decide on important } \\
\text { decisions such as infrastructure to } \\
\text { be built in my community' }\end{array}$ & $74 \%$ & $68 \%$ & $\begin{array}{c}0.06 \\
(0.04)\end{array}$ & $\begin{array}{c}\text { No } \\
\text { (Weak evidence, } \\
\text { p-value }=0.06 \text { ) }\end{array}$ \\
\hline $\begin{array}{l}\text { 'Husbands get upset when their } \\
\text { wives speak out on public issues' }\end{array}$ & $74 \%$ & $67 \%$ & $\begin{array}{c}0.07 \\
(0.04)\end{array}$ & $\begin{array}{c}\text { No } \\
\text { (Weak evidence, } \\
\text { p-value }=0.08)\end{array}$ \\
\hline
\end{tabular}

In the focus group discussions women consistently said they now feel able to speak out and be heard in the community in a way that was not possible before and said they felt more confident due to generating income. According to one woman producer group member, 'When a woman starts working in a group and making money, then it's easier for her. She begins to feel and behave differently. As soon as you have money, you start to behave differently.' Women said they were also more aware of their rights and believed that women should be considered equal and treated with respect; they learned about this from television and from trainings, including with Oxfam and LWL. It was generally acknowledged that women with high education levels, land and/or income are listened to and their opinions valued.

Women also provided examples of women leaders speaking up and influencing more powerful actors to benefit themselves and their community. In one community, when the electricity supply was turned off, all the women gathered and went to the district chairman and wrote a statement. A woman producer group member said, 'The men said, you go, nobody will listen to us. And we went. We were given the light'.

'The men said, you go, nobody will listen to us. And we went. We were given the light.'

Woman PG member 


\section{Question 8: Has participating in the GEM programme led to unintended negative outcomes?}

The evaluation recognized the potential for unintended negative outcomes from the GEM programme, especially those that are wellknown to manifest as negative outcomes in women's economic empowerment programmes due to activities that aim to shift gender roles and power dynamics in communities and households.

\section{Gender-based violence}

Gender-based violence was one such negative consequence that was important to examine, particularly as the GEM project design actively sought to empower women and encourage them to assert their own preferences, both within and outside the household - which has been found elsewhere to lead to backlash. On the other hand, such training may have had the opposite effect of decreasing acceptability of violence against women in the household and increasing the likelihood of women to report violence and seek legal support. It was not clear which of these effects might predominate.

The household survey data presents a series of important findings on gender-based violence, indicating largely positive project impact. ${ }^{15}$ In general, there is high acceptability of violence across the sample: more than 80 percent of all women interviewed felt it was acceptable for a woman to be beaten by her husband in certain cases. There was, however, evidence of a positive and significant project impact on acceptability of violence, with significantly more GEM project participants saying that violence was unacceptable in all scenarios (31 percent) than non-participants (8 percent). Table 7 (below) shows the differences between the intervention and comparison groups in specific scenarios; in almost all cases significantly fewer GEM project participants said it is acceptable for a woman to be beaten by her husband. Worryingly, over one-third of GEM project participants said it was acceptable for a woman to be beaten if her husband is drunk, only slightly (and not significantly) less than the comparison group.

\footnotetext{
${ }^{15}$ Questions around gender based violence were only asked if privacy was assured during that part of the interview to preserve confidentiality for all respondents, and at any time participants could ask to move the survey on to the next topic. The sample size for this part of the household survey is generally lower than the other questions (sample size or ' $n$ ' indicated in Table 7 ) and over $80 \%$ of the total sample.
} 
Table 7: Project impact on acceptability of violence in certain scenarios

\begin{tabular}{|c|c|c|c|c|}
\hline $\begin{array}{l}\text { 'In your opinion, is it acceptable } \\
\text { that a woman is beaten by her } \\
\text { husband if... }\end{array}$ & $\begin{array}{l}\text { Intervention } \\
(\mathrm{n}=\mathbf{2 6 2})\end{array}$ & $\begin{array}{l}\text { Comparison } \\
\qquad(n=388)\end{array}$ & Difference & $\begin{array}{c}\text { Statistically } \\
\text { significant } \\
(p<0.05) ?\end{array}$ \\
\hline $\begin{array}{l}\text { She disobeys her husband or other } \\
\text { family members' }\end{array}$ & $38 \%$ & $72 \%$ & $\begin{array}{l}-0.35 \\
(0.04)\end{array}$ & Yes \\
\hline $\begin{array}{l}\text { She neglects children or didn't } \\
\text { prepare food' }\end{array}$ & $44 \%$ & $72 \%$ & $\begin{array}{l}-0.28 \\
(0.05)\end{array}$ & Yes \\
\hline $\begin{array}{l}\text { She spends money without } \\
\text { permission' }\end{array}$ & $47 \%$ & $66 \%$ & $\begin{array}{l}-0.14 \\
(0.05)\end{array}$ & Yes \\
\hline She goes out without permission' & $53 \%$ & $67 \%$ & $\begin{array}{l}-0.14 \\
(0.05)\end{array}$ & Yes \\
\hline $\begin{array}{l}\text { He suspects that she has been } \\
\text { unfaithful' }\end{array}$ & $40 \%$ & $65 \%$ & $\begin{array}{l}-0.24 \\
(0.05)\end{array}$ & Yes \\
\hline He is drunk' & $35 \%$ & $42 \%$ & $\begin{array}{l}-0.07 \\
(0.05)\end{array}$ & No \\
\hline
\end{tabular}

In terms of prevalence of violence, the survey asked respondents if they were aware of any abusive behaviour or violent acts being committed against someone they knew over the past 12 months. The questions were deliberately indirect to take a context-sensitive approach in light of local norms and customs. ${ }^{16}$ The results therefore do not distinguish between violence committed in the community and those experienced by the respondent herself, but the expected trade-off was to elicit more responses from participants who might otherwise be reluctant to share their views at all, or who might be afraid to give honest responses.

Levels of violence experienced in communities were relatively low compared to other GEM project countries, but still 31 percent of women in the project group reported awareness of any abuse (physical or psychological) and 14 percent of the comparison group. The difference is statistically significant, but care must be taken when interpreting this data as there could be a number of explanations. It could be suggestive of negative project impact (that more violence is happening to GEM project participants and/or in their communities, potentially as a backlash to changing gender dynamics) or it could be that participating in GEM makes women more likely to identify and mention violence happening to their peers and in their communities more generally.

The supporting data provides a mixed picture. As identified in the section above, more project participants than non-participants say they feel comfortable speaking out in public and also that husbands get upset when their wives do so; this may have increased the likelihood of GEM participants' husbands being upset and using violence against them, thus potentially explaining the higher prevalence of violence reported by GEM project participants. However, there is also evidence of the latter hypothesis, that GEM women are more likely than the comparison group to identify and report on violence; the analysis revealed strong evidence of positive impact on reporting violence, with significantly more project participants saying they reported violence than non-participants (Figure

${ }^{16}$ See more on the 'neighbourhood method' here: http://www.cpcnetwork.org/research/methodology/neighborhood-method/ 
7).

Figure 7: Project impacts on gender-based violence

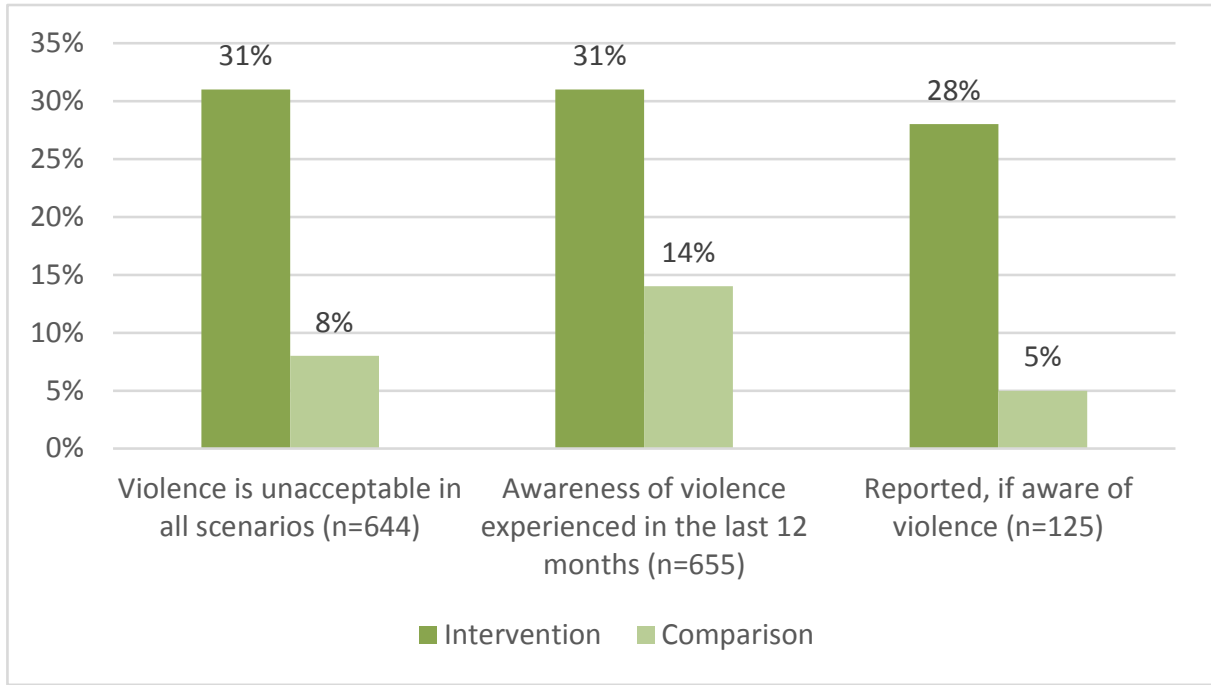

The qualitative data generated during the evaluation indicates that participating in the project did not lead to higher rates of domestic violence for GEM project participants. When asked whether there was a link between gender-based violence and the programme, community members said they believed project participants themselves were not experiencing more violence and certainly not because of the programme. Intimate partner violence was mentioned as a way to prevent women from leaving the house and participating in the programme in the first place, but not among those in the programme. As a woman in the one community said during the sense-making, 'Our husbands do not get angry - they like money we receive because of the programme.'

However, there is secondary evidence from project documents that domestic violence may have increased due to participation in the programme. The League of Women Lawyers reported that more cases of domestic violence were being reported year-on-year in the legal aid clinics; while economic stress was cited as a main driver, some women said they believed the increase was due to a backlash from their spouse due to increased participation in community platforms like GEM producer groups. ${ }^{17}$ Again there may be alternative explanations for this reported increase in intimate partner violence among project participants, such as increased awareness and reporting. However, it is an assertion that is deeply concerning and deserves further investigation and possibly action. Prior to future work on women's empowerment being approved or implemented it is suggested that first analysis is completed on the risk of violence against women in and because of the programme and appropriate processes or activities included in any intervention to proactively prevent and reduce it.

\section{Workload changes}

It was also important to understand if and how the programme may have

\footnotetext{
${ }^{17}$ Hayat, Seyed (2018) Gender, Enterprise and Markets in Tajikistan: Building Resilience, Empowering Lives.
} 
unintentionally and negatively increased workload demands and pressures for women, given it sought to encourage income opportunities for women without explicitly addressing women's unpaid care work responsibilities.

There is qualitative evidence from the focus group discussions that women have to increase their workload and sacrifice sleep in order to take advantage of economic opportunities without letting all their unpaid care work responsibilities slip. One female producer group member explained what women have had to do in order to work outside the home: 'If a woman wants her husband to let her go, then she must do everything. She will sleep less and only then she will get permission from her husband.' While husbands may be happy for their wives to bring in extra income, they expect them to do that while also keeping up their domestic duties. Another woman said, 'If a wife does a job that brings money, then [her husband] may be interested in this. But he will not do all the house work. Our husbands are spoiled. If we do not prepare the food for our husband at 12 o'clock, then he will be mad. He will immediately begin a fight.' For many women, new economic opportunities like those presented by GEM offer potential benefits but can also require more work for them and - when household work slips - entail potential problems with their husbands. Though women often mentioned that the sacrifice of leisure time felt worth it to them, there are clearly trade-offs and implications for sustainability.

Women described the trade-offs between paid and unpaid work in general, but it was not specific to their participation in GEM, and according to the quasi-experimental analysis there is no evidence that the project had a negative impact on women's workload. When asked about women's (a) available time for leisure and (b) satisfaction with leisure time, there were no significant differences observed between the intervention and comparison groups, suggesting the project did not have a negative impact on the workload of women participants (nor did it have a positive impact).

This could be because there is extra work, but women are redistributing it to others. Many women report coping with the extra work presented by extra-household economic activities by redistributing the household work to their children. Daughters and daughters-in-law were identified as being primarily responsible for the household work when older women are out of the house. One important question for the programme is whether expanding economic opportunities for some women (especially older women) has rested on increasing household responsibilities and limiting opportunities for other women, especially younger women, given that their household work transfers to their daughters or daughters-in-law in their absence. Future work would need to answer this question and perhaps explore ways in which these younger women can also access and benefit from new economic opportunities. One way would be to take steps to redistribute unpaid care work responsibilities to men as well so that all the work does not fall automatically on young women. Increased investment in technologies that reduce the amount of time or effort required for unpaid care work could also be a feature of future programmes. 
People in GEM communities did admit to men doing some of the unpaid care work in the household despite men and women generally being reluctant or hesitant to discuss men doing unpaid care work. Younger men in particular were seen to be more open to non-traditional gender roles, both encouraging their wives to be educated and work outside the home and more willing to take on household tasks themselves. During focus group discussions, several men said they will help with certain tasks, like fetching water or taking care of the cow, especially if their wives are sick or busy. A few men even said they take care of children or change diapers. Women's involvement outside the home could be contributing to these changes, meaning that instead of leading to unintended negative changes on women's workload it could be worth considering if GEM interventions may also or instead be leading to positive changes in redistributing household care work. Indeed one husband mentioned that since his wife had joined the producer group she had less time for household work so now he has taken more of the responsibility for it. This attitude is reflected in the survey results in which a very high proportion of GEM women farmers (93 percent) agree or strongly agree with the following statement: 'If the wife is working outside the home, the husband should help her with household chores.' This is only a few percentage points higher than the comparison group (88 percent) but provides weak evidence of positive impact on attitudes to husbands doing unpaid care work.

Yet this does still seem to be the exception, and most men and women were much more comfortable with the concept of women working outside the home than men doing any unpaid work inside the home. The qualitative data reveals how social norms may prevent men from doing more of the unpaid care work. Men said that they may be willing to help their wives, but they are worried what others will say; women too said that people will laugh at men who do household work. According to one man, a man who does housework will be humiliated by others: 'they will say - are you a woman? Doesn't your wife respect you?' Given how these deep-seated attitudes and norms around unpaid care work can limit women's capacities to take up new economic opportunities and also lead to increasing their workloads, it is vital that they be explicitly addressed in future interventions aimed to foster women's economic empowerment. 


\section{LEARNING AND RECOMMENDATIONS}

The GEM programme in Tajikistan has made progress in all of its main areas. Improvements have been seen in terms of women's access to resources and services, to markets, to productivity and income and to agency and decision making. However these improvements are often small and sustainability is sometimes in question. It is clear that for these changes to be sustained and to be scaled there needs to be broader support in other parts of the market and social system. This goes beyond what a programme like GEM can directly deliver and emphasizes the need for future programmes to be integrated well into the work of other actors - government, the private sector and other agencies - who are influencing other parts of the system.

\section{Enhancing women's land rights}

The GEM programme has made some significant contributions to enhancing women's land rights in Tajikistan, including policy changes, awareness raising and provision of legal services. Despite efforts to promote local government ownership of mobile legal clinics, there is no evidence that local government authorities are independently taking steps to promote awareness of women's land rights or to provide legal aid services that would support women to claim their rights in future. Without financial support from the government, legal services established during the programme are unlikely to be sustained. Future programmes should consider long-term sustainability from the design stage and develop strategies to implement these throughout the life of the project.

\section{Private sector linkages}

Positive gains have been made in building linkages with the private sector in the GEM project areas. Increased interest from farmers in improved inputs is attracting input suppliers who are starting to deliver embedded extension services. As a result of improved inputs, training and services, volumes and quality is improving. While linkages have been made between farmers and private sector companies, these relations need continued facilitation to take hold. Opportunities to build linkages to agricultural companies and processors based in the north of the country should be further explored as well as the potential offered by the border and new markets opening with Uzbekistan.

\section{Financial services}

Women farmers explained that formal bank loans are not accessible to all as they can only access them if they have a family member in formal employment and interest rates are too high. Selling household assets especially livestock - was reported to be the main strategy for women farmers to gain the investment capital they needed if they did not have 
access to formal loans. To respond to the challenges in accessing investment capital, the programme initiated a village savings and loan scheme (Savings for Change). The scheme has demonstrated positive results within a short timeframe. Future programmes should consider integrating the model when working with community groups.

In the Bangladesh GEM programme, a scheme was piloted whereby the government distributed loans for smallholder farmers through formal banks. The GEM programme partners helped local banks to identify potential loan recipients who were part of producer groups. Oxfam in Tajikistan could explore ways of sharing lessons from the Bangladesh team in influencing government to pilot a similar scheme and provide support to formal banks for designing an appropriate loan mechanism for smallholder women farmers.

\section{Women's agency and inclusion}

For women to even begin to benefit from economic opportunities they must first be able to participate in them. Almost all women said that they require permission from their husband to do anything outside the house. Young women in particular face significant barriers to participating in new economic opportunities as they lack personal agency, decision-making power and carry heavy responsibilities for unpaid care work.

- Future programmes should consider exploring and piloting different strategies to enable younger women to join and stay in groups. This may include working with younger husbands and mothers-in-law to change attitudes towards their involvement, providing shared child care during meetings, enforcing quotas for young women and providing complementary skills training valued by younger women.

- Take steps to redistribute unpaid care work responsibilities to men and introduce time-saving technologies so that all the work does not fall automatically to young women. Consider integrating the Rapid Care Analysis methodology into new and existing programmes aiming to empower women.

\section{Gender-based violence}

The data presents a series of important findings on gender-based violence, indicating largely positive project impact on decreasing the acceptability of violence and increased reporting of violence. However, in general there is high acceptability of violence across the sample of women interviewed, and some evidence that gender-based violence may have increased due to participation in the programme. This is deeply concerning and is a finding that deserves further investigation and action.

Prior to future work on women's empowerment in Tajikistan it is suggested that a) an analysis be completed on the risk of violence against women in and because of the programme, and b) appropriate processes or activities included in any intervention to proactively prevent and reduce it. Future programmes should consider joint training with husbands and wives to target men's attitudes and awareness of violence as well as women's. 
(c) Oxfam International December 2019.

This publication was written by Dr Miranda Morgan and Alastair Stewart. The authors acknowledge the assistance of Dave Bishop, Gulnora Beknazarova and Gulchegra Tabarova in its production.

For further information on the issues raised in this publication please email astewart1@oxfam.org.uk or mmorgan1@oxfam.org.uk.

This publication is copyright, but the text may be used free of charge for the purposes of advocacy, campaigning, education, and research, provided that the source is acknowledged in full. The copyright holder requests that all such use be registered with them for impact assessment purposes. For copying in any other circumstances, or for re-use in other publications, or for translation or adaptation, permission must be secured and a fee may be charged. Email policyandpractice@oxfam.org.uk.

The information in this publication is correct at the time of going to press.

Published by Oxfam GB

ISBN: 978-1-78748-537-2

DOI: $10.21201 / 2019.5372$

Oxfam GB, Oxfam House, John Smith Drive, Cowley, Oxford, OX4 2JY, UK.

\section{OXFAM}

Oxfam is an international confederation of 20 organizations networked together in more than 90 countries, as part of a global movement for change, to build a future free from the injustice of poverty. Please write to any of the agencies for further information, or visit www.oxfam.org. 